\title{
Supraclavicular extra-renal angiomyolipoma: a challenging diagnosis
}

\author{
Amrin Israrahmed (1) , ${ }^{1}$ Aviral Gupta, ${ }^{2}$ Archna Gupta, ${ }^{1}$ Rajanikant R Yadav (ㄱ) ${ }^{1}$
}

${ }^{1}$ Radiodiagnosis, Sanjay Gandhi Post Graduate Institute of Medical Sciences, Lucknow, Uttar Pradesh, India

${ }^{2}$ Pathology, Sanjay Gandhi Post Graduate Institute of Medical Sciences, Lucknow, Uttar Pradesh, India

\section{Correspondence to}

Dr Rajanikant R Yadav; rajani24478@gmail.com

Accepted 9 November 2021

Check for updates

(c) BMJ Publishing Group Limited 2021. No commercial re-use. See rights and permissions. Published by BMJ.

To cite: Israrahmed $A$, Gupta A, Gupta A, et al. BMJ Case Rep 2021;14:e247358. doi:10.1136/bcr-2021-

247358

\section{DESCRIPTION}

A 46-year-old man was referred to our department for radiological evaluation of a lesion in the right supraclavicular region for 2 months. There was no history of significant weight loss, loss of appetite or change in bowel/bladder habits. Local examination demonstrated that the lesion was firm, nontender and mobile with no discolouration of skin. High-resolution ultrasound of the lesion showed a well-defined highly vascular mass with a prominent arterial feeder from the right subclavian artery (figure 1A,B). Differential diagnosis of metastatic lymph node, vascular tumour or Castleman disease was made. Hence, contrast enhanced computed tomography (CECT) of the thorax and abdomen was performed for further evaluation. CECT showed a well-defined hyperenhancing lesion in the right supraclavicular region with no foci of calcification (figure 1C,D). A focus of macroscopic fat was seen within it, but we presumed it to be fatty hilum of an involved lymph node.

Fine needle aspiration cytology was predominantly haemorrhagic and failed to yield a diagnosis. Hence, biopsy was done which showed multiple variably sized blood vessels surrounded by smooth

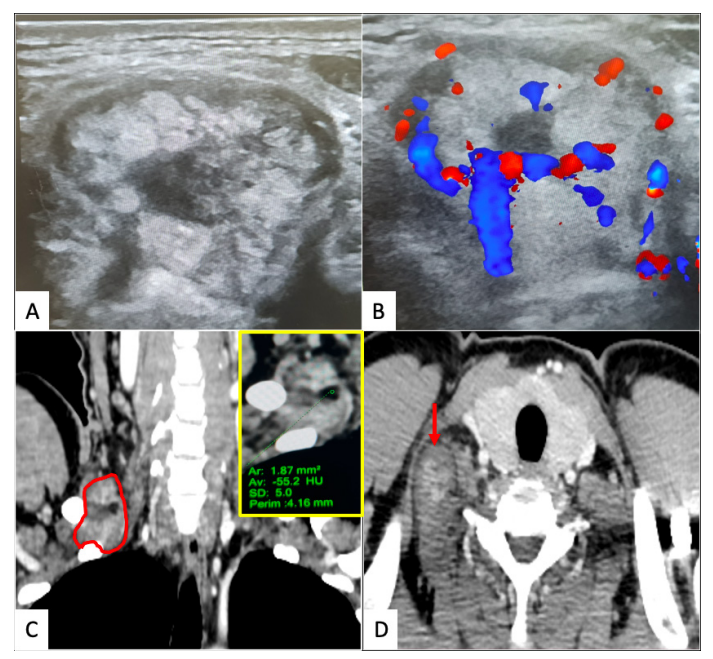

Figure 1 (A) High-resolution ultrasound image shows a well-defined heteroechoic lesion; (B) colour Doppler image shows hypervascularity within the tumour with prominent vessels at the hilum of the lesion; (C) contrast enhanced computed tomography (CECT) shows an enhancing lesion in the right supraclavicular region (outlined in red) and inset shows macroscopic fat within the lesion (-55HU); (D) axial CECT shows the right supraclavicular lesion just below the sternocleidomastoid muscle with maintained fat planes with adjacent structures.

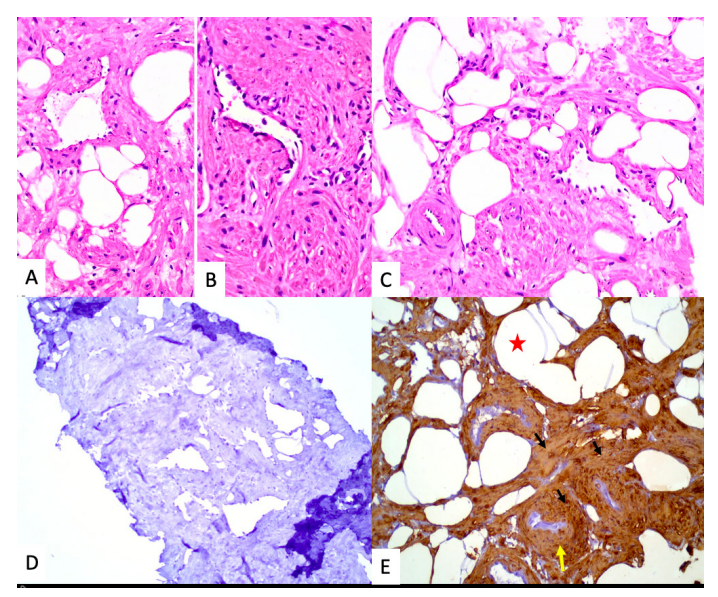

Figure 2 (A) Histopathology shows mature adipose tissue, variably dilated blood vessels and interlacing strands of smooth muscles (haematoxylin \& eosin, $200 \mathrm{x}$ ); (B) photomicrograph shows a thin wall dilated blood vessel surrounded by smooth muscle bundles (haematoxylin \& eosin, $300 \mathrm{x}$ ); (C) histopathology shows mature adipose tissue, variably dilated blood vessels and interlacing strands of smooth muscles (haematoxylin \& eosin, $100 \mathrm{x}$ );(D) HMB-45 stain negative; (E) SMA positive staining of the lesion with fat cells (red star), blood vessel (yellow arrow) and smooth muscle strands in stroma (black arrows).

muscle bundles and mature adipose tissue within (figure 2). There was no evidence of lymphoid tissue, skeletal muscles or malignant cells within the lesion. Diagnosis of extra-renal angiomyolipoma (AML) was established. The patient deferred surgery and hence he was advised annual ultrasound follow-up.

AML is a benign hamartomatous tumour, usually found in the kidney and is commonly seen in patients of tuberous sclerosis. ${ }^{1}$ Other rare extra-renal sites of AML include: cutaneous location, liver, spleen, oral/nasal cavity, retroperitoneum, mediastinum, etc. ${ }^{1}$ In our patient, the lesion was partly below the right sternocleidomastoid muscle, suggestive of a variant of cutaneous AML. Cutaneous AML was first reported by Fitzpatrick et al in 1990, and it was synonymously called angiolipoleiomyoma. ${ }^{2}$ Cutaneous AML is a rare diagnosis with only 24 cases reported in literature. ${ }^{3}$ The cutaneous/extrarenal AML differ from renal AML demographically, as the former is more common in men while renal AML is commoner in women. ${ }^{1}$ Extra-renal AML has no known association with tuberous sclerosis (TS) whereas renal AML has well-established association with TS. ${ }^{4}$ Epitheloid cells are seen in renal 
AML but are absent in extra-renal AML, hence the latter stain negative on HMB-45 stain. ${ }^{4}$ Histologically, the extra-renal AML can be differentiated from hemangioma as the latter do not show smooth muscle elements. The presence of all three components like smooth muscle, thick-walled blood vessels and mature fat

\section{Patient's perspective}

I was extremely worried about this swelling in my right neck. I had previously shown it to my local doctor, who referred me to this tertiary institute for further management. I was scared that I may have cancer, however the doctors here did some investigations and even a biopsy. I was relieved to know that the tumour is benign and not a cancer. I am quite apprehensive of undergoing a surgery and I would prefer to do regular check-ups. If needed I will undergo surgery for it at a later date. As of now I am just relieved to know that it is not cancer.

\section{Learning points}

- Renal angiomyolipoma (AML) can be seen in patients with tuberous sclerosis, however extra-renal $A M L$ is a rare diagnosis with no known association with tuberous sclerosis. Hence, there is no need for aggressive screening of patients with extra-renal AML for tuberous sclerosis.

- Extra-renal angiolipomas differ from renal AML in terms of gender predominance, clinical association and HMB-45 immunoreactivity.

- Extra-renal cutaneous variant of angiolipomas are welldefined highly vascular tumours showing macroscopic fat on cross-section imaging.

- The presence of all three elements on histology: smooth muscle bundles, thick-walled blood vessels and mature fat are diagnostic of extra-renal AML. in variable proportions is diagnostic of extra-renal AML. ${ }^{4}$ Ultrasound and CT of extra-renal AML, usually shows a well-defined highly vascular tumour with macroscopic fat and absence of calcification, but diagnosis on imaging alone is challenging and it needs to be proven histologically. Surgical resection is the treatment of choice with no propensity for recurrence. ${ }^{4}$

We suggest that in the presence of a solitary vascular lesion with macroscopic fat on cross-section imaging and in the absence of any primary malignancy on screening; extra-renal AML could be considered as a differential diagnosis.

Acknowledgements We would like to thank the radiology department for coordinating the scan effectively.

Contributors Al was primarily involved in reporting the case and drafting the manuscript. AG helped in compiling the images and in establishing the histopathological diagnosis of this case. AG contributed her expert opinion on the imaging of the case. RRY has finalized and approved the final version of this manuscript.

Funding The authors have not declared a specific grant for this research from any funding agency in the public, commercial or not-for-profit sectors.

Competing interests None declared.

Patient consent for publication Consent obtained directly from patient(s).

Provenance and peer review Not commissioned; externally peer reviewed.

Case reports provide a valuable learning resource for the scientific community and can indicate areas of interest for future research. They should not be used in isolation to guide treatment choices or public health policy.

\section{ORCID iDs}

Amrin Israrahmed http://orcid.org/0000-0002-6101-2166

Rajanikant R Yadav http://orcid.org/0000-0002-6955-850X

\section{REFERENCES}

1 Singh K, Pai R, Kini H, et al. Cutaneous angiomyolipoma. Indian J Pathol Microbiol 2009;52:242Y243

2 Fitzpatrick JE, Mellette JR, Hwang RJ, et al. Cutaneous angiolipoleiomyoma. J Am Acad Dermatol 1990;23:1093-8.

$3 \mathrm{Han} \mathrm{HH}$, Choi JY, Seo BF, et al. Radiologic misunderstanding of cutaneous angiomyolipoma in the alar base. J Craniofac Surg 2014;25:e343-4.

4 Debloom JR, Friedrichs A, Swick BL, et al. Management of cutaneous angiomyolipoma and its association with tuberous sclerosis. J Dermatol 2006;33:783-6.

Copyright 2021 BMJ Publishing Group. All rights reserved. For permission to reuse any of this content visit

https://www.bmj.com/company/products-services/rights-and-licensing/permissions/

BMJ Case Report Fellows may re-use this article for personal use and teaching without any further permission.

Become a Fellow of BMJ Case Reports today and you can:

- Submit as many cases as you like

Enjoy fast sympathetic peer review and rapid publication of accepted articles

- Access all the published articles

Re-use any of the published material for personal use and teaching without further permission

Customer Service

If you have any further queries about your subscription, please contact our customer services team on +44 (0) 2071111105 or via email at support@bmj.com.

Visit casereports.bmj.com for more articles like this and to become a Fellow 